\title{
Interpretation Consistent with International Law? The Detention of Asylum Seekers in South Africa
}

\author{
JAYA RAMJI
}

\begin{abstract}
On paper, South African law concerning detention of asylum seekers appears consistent with international standards.However, the text of the Act is vague and overly broad, permitting interpretations inconsistent with international human rights standards. Further, in practice, officials often fail to uphold even the lowest standards of the Act, in violation of South African law. In order to protect the rights of asylum seekers, the South African government should institute formal guidelines and training programs, as well as a system of strong supervision and accountability, to ensure that the Act and Regulations are interpreted in a manner consistent with international law. Such a step will enable South Africa to live up to its noble post-apartheid human rights ideals.
\end{abstract}

\section{Résumé}

Sur du papier, la loi sud-africaine sur la détention des demandeurs d'asile semble conforme aux normes internationales. Cependant le libellé de cette Loi est vague et par trop étendue, permettant ainsi des interprétations qui sont incompatibles avec les normes internationales en matière des droits de la personne. En outre, dans la pratique, bien souvent les officiels ne respectent même pas les normes minimales prévues par la Loi - en soi une violation des lois sud-africaines. S'il veut vraiment protéger les droits des demandeurs d'asile, le gouvernement sudafricain devra instaurer des directives formelles et des programmes de formation, doublés d'un système de supervision renforcée et de reddition de comptes, afin de garantir que la Loi et les Règlements soient interprétés de manière conforme au droit international. Une telle mesure permettra à l'Afrique du Sud d'honorer ses nobles idéaux de l'après-apartheid en matière des droits de la personne.

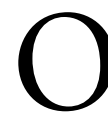
n paper, South African law relating to detention of asylum seekers generally conforms to international human rights law. Like other areas of law in this young democracy, the acts and regulations were written with high ideals. However, the legacy of apartheid, both economic and institutional, presents serious obstacles to efforts to transform these visions into a functioning human rights culture. Government officials often fail to implement the safeguards written in the law, thereby abrogating both international and domestic obligations. South African efforts to meet and surpass international human rights standards with regards to the detention of asylum seekers should be applauded and supported, but the government department responsible for refugee protection and processing, the Department of Home Affairs (DHA), should also be closely monitored to ensure that it lives up to these principles in practice.

\section{International Standards}

International human rights treaties ratified by South Africa provide broad prohibitions on arbitrary detention and restriction of freedom of movement of refugees. ${ }^{1}$ Under the South African Constitution, "[w]hen interpreting any legislation, every court must prefer any reasonable interpretation 
of the legislation that is consistent with international law over any interpretation that is inconsistent with international law." ${ }^{2}$ The United Nations High Commissioner for Refugees provides guidance in interpreting international law relating to detention of asylum seekers, finding " $[\mathrm{a}] \mathrm{s}$ a general principle, asylum seekers should not be detained." According to the Executive Committee of the UNHCR, "[d]etention may be resorted to only on grounds prescribed by law to verify identity; to determine the elements on which the claim to refugee status or asylum is based; to deal with cases where refugees or asylum seekers have destroyed their travel and/or identity documents or have used fraudulent documents in order to mislead the authorities of the State in which they claim asylum; or to protect national security or public order."4 Further, detention of refugees and asylum seekers should be subject to judicial or administrative review.5 The United Nations Human Rights Commission and the European Court of Human Rights have found that, in order to comport with international human rights law, detention should be subject to periodic review as to its legality and necessity. ${ }^{6}$

\section{Grounds for Detention}

The South African Refugees Act of 1998 and accompanying Refugee Regulations 2000 envision a system in which the majority of asylum seekers are not detained and are allowed to move freely around the country. ${ }^{7}$ This scheme is in theory consistent with international standards, as asylum seekers may be detained under the Act only for exceptional reasons. The Department of Home Affairs can withdraw an asylum seeker's permit and thereby subject her to detention if: the asylum application is held to be "manifestly unfounded," fraudulent, or abusive; the asylum seeker contravenes a condition of the permit; the asylum seeker re-enters after the application is rejected; if the asylum seeker allows her permit to lapse when leaving the country without the consent of the Minister of Home Affairs; or if the asylum seeker is ineligible for asylum due to an exclusion or cessation clause. Failure to appear for a hearing on the asylum claim may also constitute grounds for detention. ${ }^{8}$ While these reasons appear at first glance to conform to international human rights standards, the text is vague and overly broad, leaving ample space for misinterpretation and other mischief.

A closer examination of the Act reveals the nature of these problems. First, detention is used as a deterrent, to prevent and punish failure to comply with administrative requirements. While in some cases it may be consistent with international law to detain asylum seekers who contravene a condition of their permit (for reasons of national security or public order), the wording of this clause is far too broad to meet international standards. In practice, an asylum seeker can be detained for being one day late to renew her permit, an absurd result that is inconsistent with international law. Detention for re-entry after rejection is also a blunt tool that derogates international standards, unless it is used for the narrow purpose of an individualized determination whether the elements of the claim have changed since the asylum seeker's departure. Again, a lapsed permit after unauthorized departure is not in and of itself a valid reason for detention, but must meet one of the grounds laid out by the UNHCR, such as protection of public order. Finally, while failure to appear for a hearing may in some cases be a ground for detention, it cannot be a sufficient basis for detention in all cases. While the text of these clauses could be interpreted consistently with international law, the law would benefit greatly from more definite and narrower regulations or guidelines. This is true in any legal regime, but particularly so in a fledgling democracy such as South Africa, where the consistent historical practice has been denigration of rather than respect for the rights of the disempowered.

Other clauses of the Act are used to detain asylum seekers to facilitate deportation, despite the fact that deportability alone is not a valid basis for detention. For example, detention of asylum seekers whose claims are "manifestly unfounded," fraudulent, or abusive might fall under the rubric of determining the elements on which the asylum seeker's claim is based. However, the "determination" language used by the UNHCR implies at least a quasi-judicial process and presupposes that the person making the determination be versed in asylum law. In practice, it is often South African police, who have no background or training in refugee law, who are responsible for detaining asylum seekers. Moreover, even refugee officials who are ostensibly trained to make such decisions repeatedly apply asylum standards incorrectly, particularly when interpreting the vague "manifestly unfounded" standard. ${ }^{9}$ Ineligibility for refugee status due to the applicability of a cessation or exclusion clause may again be a valid ground for detention; one can imagine a situation where an asylum seeker subject to one of these clauses could be detained for national security reasons. ${ }^{10}$ However, the narrower reason for detention must be determined on a case-by-case basis; ineligibility standing alone cannot justify detention. The fact that an asylum seeker might not ultimately obtain a grant of asylum is not a sufficient ground for detention under international law. Again, the text of the Act allows room for the current practice of detention and deportation without individual examination of asylum claims through a fair and impartial process. Thus, even where the text appears superficially similar to the standards laid out by the UNHCR, the Act and Regulations are vague and overly broad, and open to interpretations inconsistent with international law. 
The problem of the vague and overly broad text is compounded by practice on the ground that departs from any reading of the Act. A pervasive lack of respect for the rights of asylum seekers combined with the absence of any accountability mechanism have resulted in frequent violations of even the lowest standards required by the Act. For example, individuals who are arrested and detained before they have been able to access the asylum application process are generally not provided with the opportunity to apply for asylum, in violation of South African law. The Regulations require that detained individuals who affirmatively claim refugee status must be issued with a permit valid for fourteen days in order to file an asylum application at a Refugee Reception Office. ${ }^{11}$ However, this directive is seldom followed at the Lindela Detention Centre, as the staff does not have sufficient training to process asylum applications, and detainees are rarely allowed to apply at the nearest Refugee Reception Office in Braamfontein. Further, the DHA does not routinely ask persons who have been arrested under the Aliens Control Act whether they intend to apply for asylum. ${ }^{12}$

A rights-respecting interpretation of the law is further stymied by the obstacles of xenophobia and corruption. There have been claims that the police arrest asylum seekers indiscriminately and without regard to their right to remain in South Africa. Asylum seekers are reportedly arrested and detained for failure to carry identity documents, on the basis of a particular physical appearance, for inability to speak any of the main national languages, or for fitting a "profile" of an undocumented migrant. ${ }^{13}$ Asylum seekers are regularly arrested by the Department of Home Affairs while applying for asylum or renewing asylum permits, for applying or renewing too late or at the wrong office, or under the charges that documents have been forged. ${ }^{14}$ Further, there have been numerous claims that police demand bribes from apprehended persons (documented and undocumented) in exchange for freedom. ${ }^{15}$ Asylum seekers who refuse to or are unable to pay such bribes remain in detention while the legality of such detention remains unexamined.

In practice, these problems with the text and the implementation of the Act interact and combine to produce pernicious results. For example, in violation of South African law, the South African Police Services reportedly destroy valid asylum-seeker permits on the assumption that such documents are fraudulent. ${ }^{16}$ Asylum seekers are then subject to detention as they have no evidence of their right to stay in the country. In practice, the burden of proof is on the arrested asylum seeker to establish her legal status in the country, in violation of the right to a presumption of innocence in international law. ${ }^{17}$ It has been reported that nei- ther the police nor the Department of Home Affairs allows persons to retrieve identification documents from their homes or allows free phone calls to contact friends or family from detention centres. ${ }^{18}$ This makes it impossible for asylum seekers to prove their right to stay in South Africa and renders such detention arbitrary and therefore in violation of international law. ${ }^{19}$ Furthermore, inefficient investigation methods and poor communication between different government departments result in lengthy delays in determination of an asylum seeker's right to stay. As a consequence, asylum seekers may be detained for days while their right to remain in the country is confirmed. ${ }^{20}$ The vagueness and overbreadth of the text of the Act permit these violations of international law, and are exacerbated by the failure of officials to uphold the safeguards in the Act.

In a laudable effort to improve the interpretation of the Act and Regulations, the Department of Home Affairs issued guidelines, effective January 2002, to address the issue of arbitrary arrest and detention by police. ${ }^{21}$ The directives require police officers to provide the Department of Home Affairs with documentary evidence of reasonable grounds for any arrest of individuals suspected of being in the country illegally. The requisite proof includes evidence that the arrested individual has been given an opportunity to prove her legal status in the country. The guidelines also provide for improved communication between the police and the DHA. These directives are an example of how the DHA can elucidate the text of the Act to ensure that it is implemented in a manner consistent with international law.

\section{Judicial Review of Detention}

The Act provides for the right to challenge the merits of the decision to detain, but again the international standards envisioned on paper are not met in practice. ${ }^{22}$ The Act establishes two levels of review of detention, one immediate and one periodic. However, the inadequate implementation of these safeguards results in a failure to protect the rights of asylum seekers.

Within forty-eight hours of detention, the asylum seeker must be brought before an immigration officer for an investigation. ${ }^{23}$ This appears at first to provide a proper safeguard, but the lack of elaboration on the process and subject matter of the investigation again leaves the door open to interpretations contrary to international standards. As discussed above, any detained individual claiming asylum should be provided with a temporary permit allowing her to report to a Refugee Reception Office and file an asylum claim within fourteen days. ${ }^{24}$ Further, any individual who has already filed an asylum claim should be immediately freed from detention unless valid legal grounds for her detention have been established. Thus very few asylum 
seekers should remain in detention after this first stage investigation. However, the procedure on the ground leaves the determination of due process and fairness to immigration officers unversed in legal standards, rather than to judges or other trained officials. Moreover, the asylum seeker is presumed to be a "prohibited person," and bears the burden of proof in establishing her eligibility to be freed from detention, again violating the international legal right to a presumption of innocence. ${ }^{25}$ If the asylum seeker fails to produce a permit demonstrating her right to remain in the country, she will be declared a "prohibited person." ${ }^{26}$ In cases of doubt, the asylum seeker may be granted a temporary permit to allow her time to provide necessary documents. The administrative nature of this process, as well as the presumption of guilt, have been criticized as contrary to the South African Constitution. ${ }^{27}$

Further, the limited rights that appear on paper are not meaningful in practice. The South African Human Rights Commission (SAHRC) has found the apprehension processes at Lindela both insufficient and arbitrary. At arrival, each person receives only a few minutes with the allocated immigration officer to present her case. Procedures have not been routinized, and it is unclear when the actual investigation is conducted and by whom. ${ }^{28}$

The next safeguard in the Act is automatic review of detention of asylum seekers after thirty days by a judge of the High Court. ${ }^{29}$ In theory, the officials responsible for detention should present detained asylum seekers to the High Court every thirty days, and are not authorized to extend detention absent such review. However, this review provision is rarely followed in practice, despite a case won by the Law Clinic of the University of the Witwatersrand and the South African Human Rights Commission (SAHRC) in November 1999, challenging the Department's repeated failure to provide such review to detainees at the Lindela Detention Centre. ${ }^{30}$ The court required that Lindela officials report the names of detainees to the SAHRC each month for compliance monitoring. These reports confirm that the DHA has continued to detain immigrants, including asylum seekers, without judicial review. According to the reports, the DHA held 752 individuals at Lindela for over thirty days between March and August 2001, and officials could not provide any evidence that these immigrants had access to the mandatory judicial review process. ${ }^{31}$

The due-process rights of asylum seekers are stymied not only by Lindela's failure to comply with the reporting requirements, but also by the officials' failure to provide notice of judicial review to detainees. In December 2000, the SAHRC reported that only one detainee with whom they met at Lindela had been informed of her right to judicial review of detention, and she was not given the opportunity to make a written submission to the court. ${ }^{32}$ The Witwatersrand High Court division has found that failure to give effective notice of an application to extend detention rendered such application unlawful. Nonetheless, the court and the executive branch have yet to improve judicial oversight of detention of asylum seekers. ${ }^{33}$

Even when an asylum seeker is able to overcome these obstacles and challenge her detention through judicial review, such review is reportedly not effective or meaningful. One NGO reports that in the Cape of Good Hope High Court division, review under the Refugees Act is heard by a judge in chambers rather than in open court. No records of such review are kept, and detainees and their legal counsel are not provided with effective notice of the DHA's application to extend the detention. While the bench is displeased with this practice, which leads to rubber-stamping of the detention decision, they continue to extend detention. ${ }^{34}$

\section{Recommendations}

It is clear that the noble aims of the Refugees Act and Regulations are being thwarted, as countless obstacles to proper implementation present themselves. These roadblocks are surmountable, however, through detailed guidelines, training, supervision, and accountability. By making affirmative efforts to respect the rights of asylum seekers, the Department of Home Affairs can and should play a central role in South Africa's transformation into a climate protective of human rights.

First, the DHA should issue guidelines to government officials and police officers to inform their interpretation of the Act and Regulations. The January 2002 directives concerning the arrest and detention of undocumented migrants by the South African Police Services are a step in the right direction. However, this page-long list of missives should be followed up with a comprehensive framework of guidelines concerning detention of asylum seekers. These guidelines should follow the determinations of the Executive Committee of the UNHCR, and in this way direct immigration officials and police officers to interpret the Act and Regulations consistent with international standards. Possible topics include, but are not limited to, interpretation of grounds for withdrawal of asylum seeker permits; the definition of "manifestly unfounded," "fraudulent," or "abusive"; fairness, burdens of proof, and due process in determination of validity of asylum seeker documentation; detainee access to asylum application procedures; investigation of legality of detention; and notice of right to and access to judicial review of detention.

Second, Refugee Reception Officers, immigration officials, and police officers alike should be required to partici- 
pate in comprehensive training courses on asylum law and refugee rights. The courses would outline refugee rights under international law as well as proper interpretation and implementation of the Act and Regulations, and would include a unit on detention of asylum seekers. The UNHCR has sponsored training sessions for Refugee Reception Officers which, while comprehensive and informative, have not been absorbed or internalized by the participants. This problem could be resolved by reinforcement from supervisors of the importance of the training, as well as rigorous written and oral examinations at the end of the course. For full impact, the results of such examinations should directly affect the placement and promotion of officials taking the course. Further, in order to fully protect the rights of asylum seekers, immigration officials generally as well as police officers must be required to participate in such courses and to garner high marks in the examinations.

Third, supervisors in the DHA and the South African Police Services (SAPS) must emphasize the importance of creating a climate protective of human rights. This includes praising and promoting officers and officials who take steps to protect the rights of detained asylum seekers as well as criticizing and sanctioning those who consistently violate the rights of detainees. Supervisors should also provide guidance to officers and officials in interpreting the Act and Regulations, and should point out incorrect understandings and commend proper interpretations of the law. Moreover, supervisors should be held responsible for the actions of officials and officers under their watch, and should be encouraged in their efforts to protect the rights of asylum seekers and punished for repeated and/or egregious rights violations. Effective supervision of this nature would not only help asylum seekers, but would benefit South African society generally in its transition to democracy by promoting the internalization of human-rights norms

Finally, immigration officials and police officers must be held accountable for violations of South African law and international human-rights standards. Complaints of mistreatment by asylum seekers should be taken seriously, and a formal procedure should be created to investigate and respond to such complaints. This is particularly important for detained asylum seekers, whose environment is entirely controlled by DHA officials. Officials and officers who are the subject of repeated verified complaints should undergo intensive rights training and face disciplinary charges if their behaviour does not improve. Further, officials should be held accountable for failures to comply with the Act, particularly with respect to judicial review provisions. Again, a formal mechanism to examine compliance with an international human rights interpretation of the Act should be created, and should permit asylum seekers and NGOs to lodge complaints against officials who have failed to uphold the rights of asylum seekers to be free from detention except under circumscribed and specifically enumerated conditions, and to obtain judicial review of such detention.

The implementation of the Refugees Act and Regulations has occurred in theory, but the Department of Home Affairs must work hard to ensure that the international human rights standards outlined in the law are met in practice. South Africa is finally on its way to becoming a respected member of the international community, committed to upholding international human rights law. While there will be obstacles along that road, the government should be encouraged to take the steps outlined above to ensure that the rights of detained asylum seekers are respected. NGOs play an important watchdog role in this process, but the judiciary and the DHA itself must also strive to meet international human rights standards with respect to every asylum seeker detained under the Act.

\section{Notes}

1. African [Banjul] Charter on Human and Peoples' Rights, 23 October 1986, art. 6, in Twenty-four Human Rights Documents (New York: Center for the Study of Human Rights, Columbia University, 1992) at 118; Convention Relating to the Status of Refugees [Refugee Convention], 28 July 1951, 19 U.S.T. 6259, 189 U.N.T.S. 150, art. 26 (entered into force 22 April 1954); International Covenant on Civil and Political Rights, G.A. Res. 2200A (XXI), U.N. GAOR, $21^{\text {st }}$ Sess., Supp. No. 16, at 52, U.N. Doc. A/6316 (1966), 999 U.N.T.S. 171 (entered into force 23 March 1976), reprinted in 6 I.L.M. 368 (1967), at Art. 9(1) ("ICCPR"). It is important to note that an individual becomes a refugee as soon as she has been forced to flee her country of origin due to persecution; thus many asylum seekers may technically be classified as refugees. See Guy S. Goodwin-Gill, The Refugee in International Law (New York: Oxford University Press, 1998) at 32.

2. Constitution of the Republic of South Africa, 1996, art. 233.

3. Office of the United Nations High Commissioner for Refugees, UNHCR Revised Guidelines on Applicable Criteria and Standards Relating to the Detention of Asylum Seekers, February 1999, No. 2.

4. Executive Committee of the United Nations High Commissioner for Refugees, Conclusions on the International Protection of Refugees, No. 44: "Detention of Refugees and Asylum Seekers," $37^{\text {th }}$ Sess. (1986).

5. Ibid.

6. See A v. Australia, United Nations Hum. Rts. Cttee., Communication No. 560/1993: Australia. 30/04/97, UN Doc. No. CCPR/C/59/D/560/1993 (30 April 1997); Amuur v. France, Eur. Ct. Hum. Rts., Case No. 17/1995/523/609 (20 May 1996).

7. While beyond the scope of this paper, it is important to note that asylum seekers' right to freedom of movement in South Africa 
has been curtailed by renewal requirements for asylum-seeker permits that are excessively restrictive both temporally and geographically.

8. Refugees Act No. 130 of 1998, arts. 23, 22(5) (Republic of South Africa) (“Act”); Refugee Regulations No. 21075, \$\$ 8, 9 (6 April 2000) (Republic of South Africa) ("Regulations").

9. In the author's experience, the Braamfontein Refugee Reception Office in Johannesburg misapplied the "manifestly unfounded" definition more often than not. In one particularly egregious case, a Tamil asylum seeker from northern Sri Lanka was rejected as "manifestly unfounded" simply because the officials were unfamiliar with the political situation in Sri Lanka.

10. Article 1(C) of the Refugee Convention outlines the cessation clauses, which include: voluntary re-availment of the country of nationality; voluntary reacquisition of a lost nationality; acquisition of a new nationality and protection of the country of the new nationality; voluntary re-establishment in the country of persecution; and changed circumstances in the country of nationality or former nationality that terminate the conditions leading to her recognition as a refugee with a "compelling reasons" exception for victims of past persecution. Article $1(\mathrm{~F})$ of the Refugee Convention outlines the exclusion clauses, which include serious reasons for considering that the refugee has committed: a crime against peace, a war crime, or a crime against humanity; a serious non-political crime outside the country of refuge prior to admission as a refugee; or acts contrary to the purposes and principles of the United Nations. The former clause can be used to terminate refugee status after it has been granted; the latter is a bar to the granting of refugee status.

11. See Refugee Regulations 2000 at $\$ 2(2)$; Jonathan Klaaren, $A$ Guide to South African Refugee Law (May 1999) at 26.

12. See Emma Algotsson, Lindela: At the Crossroads for Detention and Repatriation (Johannesburg: South African Human Rights Commission, December 2000) at 48-49.

13. Ibid. at 12.

14. See correspondence with Emma Algotsson, Lawyers for Human Rights, Pretoria, South Africa, July 24, 2001 [on file with author; obtained in connection with Lawyers' Committee for Human Rights report].

15. See Illegal? Report on the Arrest and Detention of Persons in Terms of the Aliens Control Act, (South African Human Rights Commission (SAHRC"), March 1999) at 23-25.

16. Ibid.

17. See ICCPR at art. 14(2). While immigration offenses arguably may not be criminal offenses, the punishment of deportation is at least as severe as imprisonment, particularly for asylum seekers, and should therefore be held to the same due process standards as criminal law.

18. Supra note 15 at $23-25$.

19. See ICCPR at Art. 9(1).

20. Supra note 12 at 12.

21. See Department of Home Affairs, Passport Control Instruction No. 77 of 2001: Arrest and Detention of Illegal Aliens by the SAPS [on file with author].
22. It is important to note that this article does not examine judicial review of the claim to asylum, but solely judicial review of the decision to detain.

23. See Aliens Control Act $\$ 55(1)$.

24. See Refugee Regulations $2000 \$ 2(2)$.

25. See ICCPR at art. 14(2); supra note 17.

26. Aliens Control Act, $\$ \$ 7,9$.

27. See Jonathan Klaaren, The Detention and Repatriation of Undocumented Migrants, Working Paper prepared for the South African Human Rights Commission (May 28, 1999) [unpublished, on file with author] at 4.

28. Supra note 12 at 13.

29. See Refugees Act of 1988 at art. 29(1).

30. See The South African Human Rights Commission and Forty Others v. Minister of Home Affairs and Dyambu (Pty) Ltd., case no. 28367/99, Witwatersrand High Court (South Africa). The High Court is an independent and widely respected court. It is similar in function to a federal district court in the United States, as it largely hears first instance trials but also adjudicates some appeals.

31. See correspondence with Emma Algotsson, April 3, 2002 [on file with author].

32. Supra note 12 at 13.

33. See Fei Lui v. Commanding Officer, 1999 (3) SALR 996 (W); correspondence with Frankie Jenkins, Human Rights Committee, Cape Town, South Africa, August 21, 2001 [on file with author; obtained in connection with Lawyers' Committee for Human Rights report]. This case concerns $\$ 55(5)$ of the Aliens Control Act, the predecessor to \$29(1) of the Refugees Act of 1998. In this case, the detainee received notice of the application to extend on the same day that the case was heard. 34. Ibid.

Jaya Ramji holds a J.D. from Yale Law School and is a litigation associate at Debevoise \& Plimpton in New York, where she is currently drafting a report on comparative law and practice of detention of asylum seekers as a pro bono project with the Lawyers' Committee for Human Rights. In 2000, she was a Robert L. Bernstein Fellow in International Human Rights, based at the Refugee Law Clinic of the University of the Witwatersrand, Johannesburg, South Africa, where she represented asylum seekers, challenged DHA practices that violated international standards, and assisted the UNHCR in conducting training sessions on asylum law for DHA officials. Portions of this article have been drawn from the research used in the LCHR report and from the author's experiences in South Africa. The author would like to thank Eleanor Acer, Emma Algottson, Ahilan Arulanantham, Nelson Tebbe, Frankie Jenkins, and Professor Jonathan Klaaren. 